\title{
Correction to: Religion and Attitudes Towards Abortion and Euthanasia Among Young People in Poland and Norway
}

\author{
Pål Ketil Botvar, Claudia Sarti, Katarzyna Zielińska,
} and Marcin K. Zwierżdżyński

\section{Correction to:}

Chapter 10 in: H.-G. Ziebertz, F. Zaccaria (eds.), Euthanasia, Abortion, Death Penalty and Religion - The Right to Life and its Limitations, Religion and Human Rights 4, https://doi.org/10.1007/978-3-319-98773-6_10

Owing to an oversight, the affiliations of the second and the fourth authors of this book were published with errors. The correct presentation is as below.

C. Sarti

Independent Researcher, Nijmegan, The Netherlands

e-mail: claudiasarti@gmail.com

\section{K. Zwierżdżyński}

AGH University of Science and Technology, Kraków, Poland e-mail: marcinz@agh.edu.pl 